\title{
The bromine content of human tissue
}

\author{
By R. F. CRAMPTON, P. S. ELIAS AND S. D. GANGOLLI \\ The British Industrial Biological Research Association, \\ Woodmansterne Road, Carshalton, Surrey and Department of Health and \\ Social Security, London
}

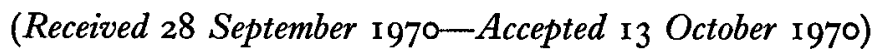

\begin{abstract}
I. A comparison of human tissue organo-bromine residues has been made from specimens obtained in the UK, West Germany and Holland.

2. These findings, in conjunction with previous animal studies and with the geographical differences in the use of brominated vegetable oils as food additives, suggest that the high bromine levels found in the fat of tissues from UK children are due to the use of these compounds.
\end{abstract}

This study was undertaken as a result of the findings of I. F. Gaunt, P. Grasso \& S. D. Gangolli (I97I) and I. F. Gaunt, S. D. Gangolli \& R. F. Crampton (I97I). Brominated vegetable oils, which have been used as food additives for over 20 years in the UK and elsewhere, were found to produce high bromine residues in all organ fat of rats and pigs. To confirm these findings in man by direct experimentation would have created a number of difficulties, including the necessity of serial biopsies. Advantage was therefore taken of the fact that in Holland and West Germany brominated vegetable oils have not been used as food additives (for reasons unrelated to their safety in use). A comparison has been made between the bromine levels of human tissues obtained in the UK, in Holland and West Germany.

Although human tissue levels of inorganic bromine have been reported (Spector, 1956), no comparable data exist for organo-bromine levels.

\section{EXPERIMENTAL}

Human tissues. Specimens of human tissues obtained at autopsy, preserved by deepfreezing, were received together with particulars of the subject from pathologists in the United Kingdom, West Germany and Holland. Details of the specimens examined are shown in Table $\mathbf{I}$.

Determination of lipid-bound bromine. The specimen was thawed and a weighed amount of minced tissue was mixed with acid-washed sand in a steel dish. The dish and contents were dried in an air oven at $100-105^{\circ}$ for $4 \mathrm{~h}$. The dried material was transferred to a Soxhlet extractor and extracted with diethyl ether (AR) for $8 \mathrm{~h}$. The extract was evaporated to dryness and the weight of fat determined. To a weighed portion of extracted fat in a nickel crucible, $2 \mathrm{ml}$ of $5 \mathrm{~N}$-alcoholic $\mathrm{KOH}$ were added; the mixture was heated on a boiling water-bath until free from alcohol, and then transferred to a muffle furnace at $500^{\circ}$ for $2 \mathrm{~h}$. The cooled ash was repeatedly extracted with hot distilled 
water, made up to $10 \mathrm{ml}$, centrifuged at $3000 \mathrm{rev} . / \mathrm{min}$ for $5 \mathrm{~min}$ and the bromine content of the aqueous supernatant fraction determined by the method of Hunter (1955).

Table I. Description and source of specimens examined

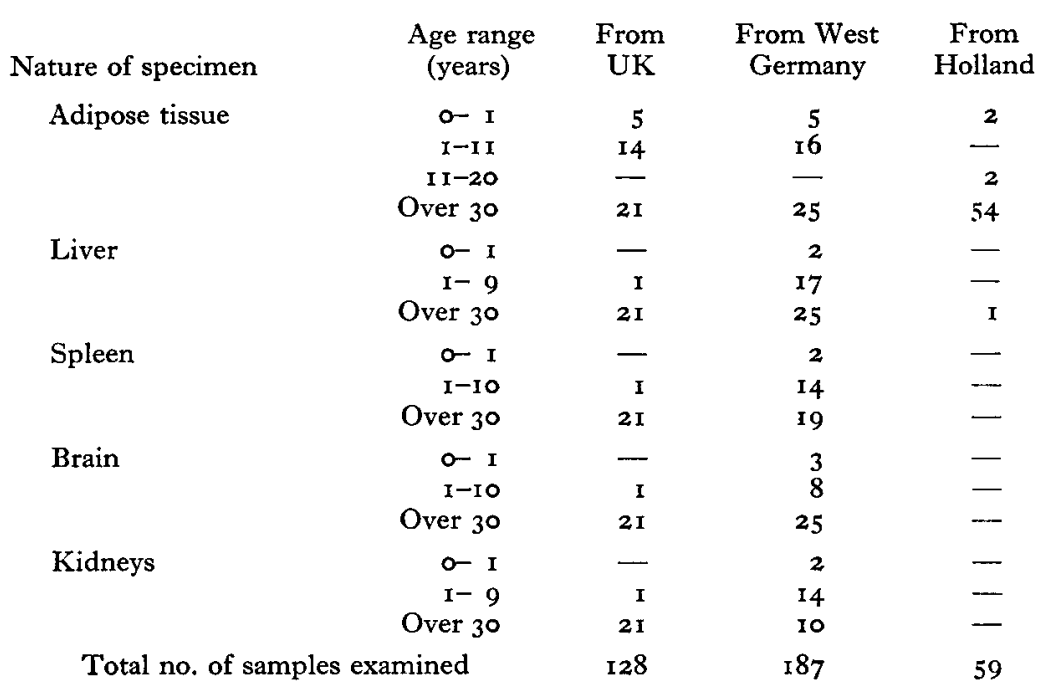

\section{RESULTS}

The lipid-bound bromine contents of adipose tissue and organs from specimens collected in the UK are shown in Table 2. The samples from neonates contained no detectable amounts of bromine. The bromine levels in adipose tissue from infants were negligible, but in the specimens from children up to the age of I I, appreciable amounts of bromine were found ( $1 \cdot 7-10.9 \mathrm{mg} / 100 \mathrm{~g}$ fat $)$. The lipid-bound bromine contents in the organs from children were considerably higher than in adipose tissues. In adults, the bromine levels in adipose tissue were low and ranged from less than 0.01 to $0.43 \mathrm{mg} / \mathrm{r} 00 \mathrm{~g}$ fat; the values were slightly higher in the organs. There were no differences related to sex or age distribution in the values derived from the adult group.

The lipid-bound bromine levels in adipose tissues and organs of samples of West German origin are shown in Table 3 . In all instances the bromine content of the fatty tissues was low, and ranged from 0.07 to $0.94 \mathrm{mg} / \mathrm{ro0} \mathrm{g}$ fat in children and less than $0.0 \mathrm{I}-0.09 \mathrm{mg} / \mathrm{r} 00 \mathrm{~g}$ fat in adults. The lipid bromine contents of the organs were also low, ranging from less than $0.0 \mathrm{I}$ to $0.94 \mathrm{mg} / \mathrm{r} 00 \mathrm{~g}$ fat.

The results for the bromine contents in the specimens received from Holland are shown in Table 4. The results show that in all the tissues examined the bromine content was low and ranged from 0.01 to $0.25 \mathrm{mg} / 100 \mathrm{~g}$ fat.

The largest amounts of lipid-bound bromine were found in the tissues from children in the UK. The levels of bromine in the adipose tissue of this group were approximately ten times the amounts found in the specimens from children of a similar age-group from West Germany, and the lipid-bound bromine levels in the organs of UK origin were twenty to fifty times higher than those in the West German specimens. 
Table 2. Lipid-bound bromine contents of specimens from the UK

\begin{tabular}{|c|c|c|c|c|c|c|c|}
\hline \multirow[b]{2}{*}{$\begin{array}{l}\text { Source of } \\
\text { specimens }\end{array}$} & \multirow[b]{2}{*}{ Age } & \multirow[b]{2}{*}{ Sex } & \multicolumn{5}{|c|}{$\begin{array}{l}\text { Lipid-bound bromine content, } \\
\text { expressed as } \mathrm{mg} / \mathrm{lo0} \mathrm{g} \text { fat }\end{array}$} \\
\hline & & & $\begin{array}{l}\text { Adipose } \\
\text { tissue }\end{array}$ & Liver & Spleen & Brain & Kidneys \\
\hline Placenta & & & $<0.01$ (4) & & & & \\
\hline \multirow[t]{15}{*}{ Children } & $6 \mathrm{~d}$ & q & $<0.01$ & - & - & - & - \\
\hline & 21 & $0^{*}$ & 4.23 & - & - & - & - \\
\hline & 3 & 우 & $5 \cdot 15$ & $25 \cdot 2$ & - & - & $3 \mathrm{I} \cdot 7$ \\
\hline & $4 \cdot 5$ & $0^{*}$ & $4 \cdot 27$ & - & - & - & - \\
\hline & 5 & $\hat{o}$ & $3 \cdot 63$ & - & - & - & - \\
\hline & 5 & $\sigma^{\circ}$ & $2 \cdot 32$ & - & - & - & - \\
\hline & 6 & $q$ & $2 \cdot 39$ & - & - & - & - \\
\hline & years & 0 & 3.74 & - & - & - & - \\
\hline & 7 & 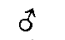 & $4 \cdot 54$ & - & -- & - & - \\
\hline & 8 & ô & 5.40 & - & - & - & - \\
\hline & 9 & ô & 10.9 & - & - & - & - \\
\hline & Io & $\pi$ & 4.25 & - & $47 \cdot 4$ & $36 \cdot 4$ & - \\
\hline & 10 & 운 & $6 \cdot 4 \mathrm{I}$ & - & - & - & - \\
\hline & I I & $\hat{0}$ & $1 \cdot 77$ & - & - & - & - \\
\hline & Unknown & $\hat{o}$ & I.87 & - & - & - & - \\
\hline Adults & $30-7$ I years & & $0-0.43(21)$ & $-0.73(21$ & $-0.47(2 \mathrm{I})$ & $-0 \cdot 79(21)$ & $0-0.57(2 \mathrm{I})$ \\
\hline
\end{tabular}

Figures in parentheses refer to number of samples examined.

Table 3. Lipid-bound bromine contents of specimens from West Germany

Source of specimens Children

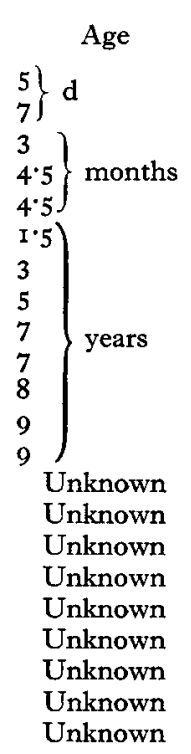

Lipid-bound bromine content, expressed as $\mathrm{mg} / \mathrm{I} 00 \mathrm{~g}$ fat

Adults $30-75$ years

\begin{tabular}{|c|c|c|c|c|}
\hline $\begin{array}{c}\text { Adipose } \\
\text { tissue }\end{array}$ & Liver & Spleen & Brain & Kidneys \\
\hline 0.40 & $0 . I I$ & 0.26 & 0.06 & 0.13 \\
\hline 0.64 & - & - & - & - \\
\hline 0.94 & 一 & - & - & - \\
\hline 0.20 & - & - & - & - \\
\hline 0.15 & 0.64 & 0.59 & 0.16 & 0.86 \\
\hline 0.28 & 0.59 & 0.44 & O.II & 0.70 \\
\hline 0.34 & 0.85 & 0.01 & 0.27 & 0.10 \\
\hline 0.56 & 0.74 & 0.82 & 0.14 & 0.44 \\
\hline 0.24 & 0.94 & 0.12 & - & 0.26 \\
\hline- & $<0.01$ & 0.36 & - & 0.42 \\
\hline 0.17 & 0.32 & 0.71 & - & 0.25 \\
\hline 0.57 & 0.17 & $O \cdot I_{I}$ & 一 & 0.50 \\
\hline 0.15 & 0.27 & 0.68 & - & - \\
\hline 0.07 & 0.35 & 0.17 & 0.47 & 0.31 \\
\hline 0.52 & 0.20 & 0.66 & $0 \cdot 17$ & $0 \cdot 11$ \\
\hline 0.31 & 0.23 & 0.07 & - & - \\
\hline 0.16 & $0.8 I$ & 0.76 & - & 0.19 \\
\hline 0.69 & 0.17 & - & - & 0.16 \\
\hline 0.12 & 0.40 & - & - & 0.60 \\
\hline 0.82 & 0.43 & 0.16 & 0.71 & 0.85 \\
\hline 0.44 & 0.87 & 0.13 & 0.50 & 0.49 \\
\hline 0.39 & 0.83 & 0.30 & 0.14 & 0.52 \\
\hline
\end{tabular}

Figures in parentheses refer to number of samples examined. 
A comparison of the lipid-bound bromine levels in the specimens of adipose tissue from adults in the three countries showed that almost half the specimens had less than $0.01 \mathrm{mg}$ bromine in $100 \mathrm{~g}$ fat. The highest levels found were in the specimens from the $\mathrm{UK}$, where $5.6 \%$ of the specimens had bromine levels in the range of $0.40-0.45 \mathrm{mg} /$ $100 \mathrm{~g}$ fat. In the Dutch specimens, two of the fifty-four $(\mathrm{r} \cdot 6 \%)$ had bromine levels ranging from 0.35 to $0.40 \mathrm{mg} / \mathrm{I} 00 \mathrm{~g}$ fat. The West German specimens had the lowest amounts of lipid-bound bromine.

\section{Table 4. Lipid-bound bromine contents of specimens from Holland}

\begin{tabular}{|c|c|c|c|c|}
\hline \multirow{2}{*}{$\begin{array}{l}\text { Source } \\
\text { of } \\
\text { specimens }\end{array}$} & \multirow[b]{2}{*}{ Age } & \multirow[b]{2}{*}{ Sex } & \multicolumn{2}{|c|}{$\begin{array}{l}\text { Lipid-bound bromine content } \\
\text { expressed as } \mathrm{mg} / \mathrm{r} 00 \mathrm{~g} \text { fat }\end{array}$} \\
\hline & & & Adipose tissue & Liver \\
\hline Children & $\begin{array}{l}3.5 \text { months } \\
4 \text { months } \\
\text { I } 8 \text { years }\end{array}$ & $\begin{array}{l}\text { (I) }{ }^{\star} \\
\text { (I) Unknown } \\
\text { (r) } \sigma^{\star}\end{array}$ & $\begin{aligned}< & 0.01 \\
< & 0.01 \\
& 0.12\end{aligned}$ & - \\
\hline Adults & $20-70$ years & & $0.1-0.37(54)$ & $0.21(1)$ \\
\hline
\end{tabular}

Figures in parentheses refer to number of samples examined.

\section{Table 5. Environmental bromine compounds}

$\begin{array}{ll}\text { Inorganic bromide } & \text { Drugs } \\ \text { Ethylene dibromide } & \text { Fuel additive } \\ & \text { Fumigant } \\ \text { Methyl bromide } & \text { Fumigant } \\ \text { Methylene chlorobromide } & \text { Fire extinguishers } \\ \begin{array}{l}\text { Potassium bromate } \\ \text { Tetrabromofluorescein } \\ \text { (Eosin) }\end{array} & \begin{array}{l}\text { Flour additive } \\ \text { Monobromoacetic acid esters } \\ \text { (prohibited in 1950) }\end{array} \\ \end{array}$

\section{DISCUSSION}

The relatively elevated levels of lipid-bound bromine found in the UK specimens, particularly in those from children, suggest that the UK population has been exposed to bromine-containing compounds to a greater extent, resulting in the accumulation of bromine in adipose tissues in amounts larger than those found in specimens from the other two countries. The possible implication, in this context, of organo-bromine compounds in the form of drugs, industrial chemicals and food additives was therefore explored.

Some environmental chemicals containing bromine are shown in Table 5. It is difficult to see how any of these compounds could be responsible for the considerable differences in the tissue residues of bromine between UK and continental children. Inorganic compounds are readily excreted and are present only in the aqueous phase of tissues (Goodman \& Gilman, I 965). Only the brominated vegetable oil has the necessary distribution to explain the epidemiological differences. Moreover, the results found in UK children are those expected from previous animal findings. Industrial com- 
pounds of bromine which are known to accumulate in body fat (ethylene dibromide, methyl bromide and methylene chlorobromide) are relatively rapidly converted into inorganic bromides (Abreu \& Emerson, I940; Clarke, Roworth \& Holling, 1945; Gay, 1962; Miller \& Haggard, I943; Von Oettingen, 1964; Svirbely, Highman, Alford \& Von Oettingen, 1947), and would have appeared predominantly in the tissues of adult males.

The monobromoacetic acid ethylene glycol ester has never been used as a food additive in the UK. Its use as such in France and Holland was banned in $195^{\circ}$ owing to its toxic effects (Dalgaard-Mikkelsen, Kvorning \& Møller, 1955; Le Poidevin, r965).

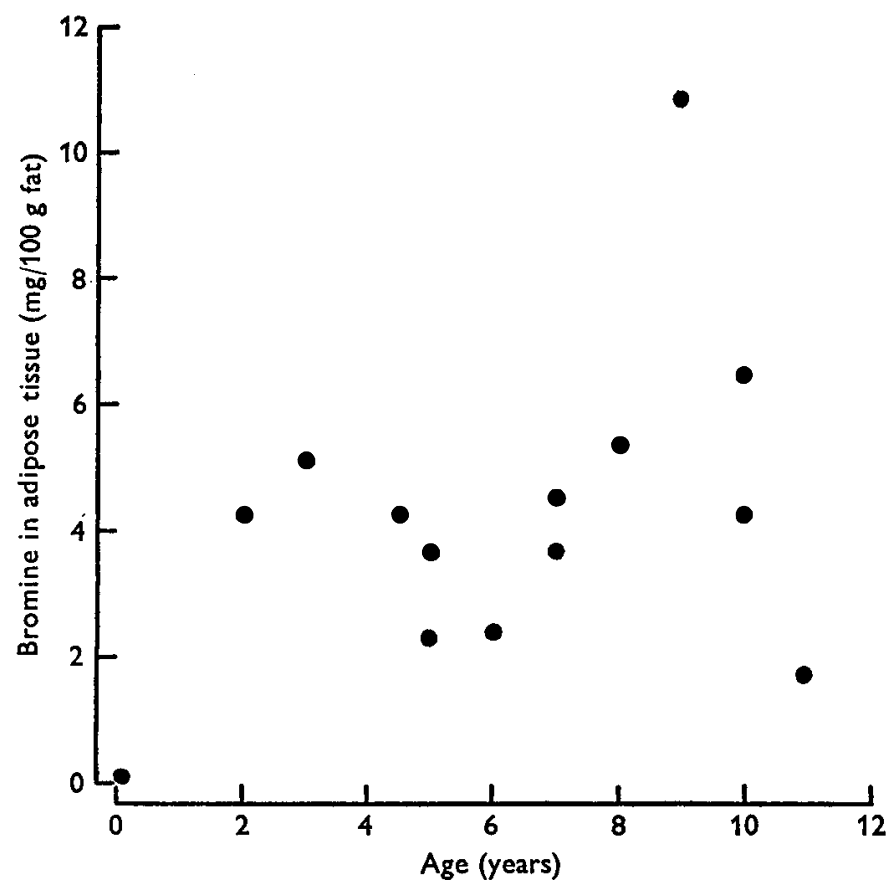

Fig. I. Bromine concentration in adipose tissues from UK children.

In the UK, brominated vegetable oils, permitted at levels to $80 \mathrm{ppm}$ in soft drinks, may contribute about $\mathrm{I}-2 \mathrm{mg}$ bromine/d, if a daily intake of about $500 \mathrm{ml}$ of soft drinks is assumed. As soft drinks are predominantly consumed by children, the results presented in Fig. I suggest some positive correlation between age and bromine residues in adipose tissue, though more information, particularly for neonates and in the age-group of IO- 18 years, is required before any more definite conclusions could be reached. Tissue from children in these age-groups is difficult to obtain. As the majority of tissue specimens were obtained post mortem, no information on estimated soft drink intake could be obtained. In spite of the several deficiencies in this study, it seems highly probable that the intake of brominated vegetable oil is the cause of the tissue bromine residues in children.

The use of brominated oils as food additives has been banned in the UK as from September 1970 . 
We acknowledge with gratitude the specimens of human tissues received from: Prof. Dr med. Zimmermann, Chefarzt des Pathologischen Institut, Krankenhaus Frankfurt A.M. -623 Frankfurt (Main)-Höchst, Gotenstrasse 6-8, Germany; Dr G. J. van Esch, Head of Laboratory of Toxicology, Rijks Instituut voor de Volksgezondheid, Sterrenbos I, Utrecht, The Netherlands; Department of Pathology, Queen Mary's Hospital, Carshalton. We thank Miss Fay Woods for her technical assistance.

\section{REFERENCES}

Abreu, B. E. \& Emerson, G. A. (1940). Univ. Calif. Publs Pharmac. 1, 313.

Clarke, C. A., Roworth, C. G. \& Holling, E. H. (I945). Br. F. ind. Med. 2, I7.

Dalgaard-Mikkelsen, S., Kvorning, S. A. \& Moller, K. O. (1955). Acta Pharmac. tox. II, I3.

Gaunt, I. F., Gangolli, S. D. \& Crampton, R. F. (I971). Fd Cosmet. Toxicol. 9, I3

Gaunt, I. F., Grasso, P. \& Gangolli, S. D. (I97I). Fd Cosmet. Toxicol. 9, r.

Gay, H. H. (I962). Ind. Med. Surg. 31, 438 .

Goodman, L. S. \& Gilman, A. (1965). The Pharmacological Basis of Therapeutics 3rd ed. New York: Macmillan and Company.

Hunter, G. (1955). Biochem. F. 60, $26 \mathrm{r}$.

Le Poidevin, N. (1965). Acta Pharmac. tox. 23, 98.

Miller, D. P. \& Haggard, H. W. (1943). F. ind. Hyg. Toxicol. $25,423$.

Spector, W. S. (1956). The Handbook of Biological Data. Philadelphia, Pa: Saunders.

Svirbely, J. L., Highman, B., Alford, W. C. \& von Oettingen, W. F. (1947). F. ind. Hyg. Toxicol. $29,382$.

Von Oettingen, W. F. (I 964). The Halogenated Hydrocarbons of Industrial and Toxicological Importance. Amsterdam: Elsevier Publishing Company. 